\title{
THE DIVERSE CHEMICAL FORMS OF HEAVY METALS IN TISSUE EXTRACTS OF SOME METALLOPHYTES FROM SHABA PROVINCE, ZAÏRE
}

\author{
Richard S. Morrison, ${ }^{*}$ Robert R. Brooks, ${ }^{*}$ Roger D. Reeves, ${ }^{*}$ François Malaisse, $\dagger$ Pall Horowitz, $\ddagger$ \\ Michael aronson $\ddagger$ and George R. Merriam $\$ \dagger$
}

* Department of Chemistry, Biochemistry and Biophysics, Massey University, Palmerston North, New Zealand; $†$ Laboratoire de Botanique et Écologie, Universite Nationale du Zaire, Lubumbashi, Zaire; $†$ Department of Physics, Harvard University, Cambridge, MA, U.S.A.; $\$$ National Institutes of Health, Bethesda, MD, U.S.A.

(Revised received 16 June 1980 )

Key Word Index-Aeolanthus biformifolius; Buchnera henriquesii; Faroa chalcophila; Haumaniastrum robertii; Silene cobalticola; cobalt; copper; proton microprobe; metallophytes.

\begin{abstract}
Copper and cobalt were determined in tissue extracts of five metallophytes from Shaba Province, Zaïre. About $40 \%$ of the cobalt and copper was extractable into deionized water and a further $40 \%$ was extractable in $0.2 \mathrm{M}$ hydrochloric acid. It was concluded that copper and cobalt are bound to several different ligands instead of a single ligand as in the case of nickel hyperaccumulators. Proton microprobe studies on the cobalt accumulator Haumaniastrum robertii showed a strong inverse correlation between the spatial distributions of cobalt and potassium, as well as a direct relationship between cobalt and calcium. It is suggested that some of the cobalt may be immobilized with calcium in oxalate crystals.
\end{abstract}

\section{INTRODUCTION}

A number of plants from Shaba Province, Zaïre have been found to accumulate large concentrations $(>1000$ $\mu \mathrm{g} / \mathrm{g}=>0.1 \%$ ) of copper and cobalt [1-10] and are endemic to about 100 copper/cobalt ore deposits which total some $20 \mathrm{~km}^{2}$ in a $20000 \mathrm{~km}^{2}$ area of the province. These species not only accumulate copper and cobalt to a high degree, but also have a tolerance to both metals [10]. Prominent among these metallophytes are: Haumaniastrum robertii [3] containing up to $10200 \mu \mathrm{g} / \mathrm{g}(1.02 \%)$ cobalt in dried leaves; Buchnera henriquesii [9] with up to $3520 \mu \mathrm{g} / \mathrm{g}$ copper and $1510 \mu \mathrm{g} / \mathrm{g}$ cobalt; Aeolanthus biformifolius $[6,7]$ with up to 3920 and $2820 \mu \mathrm{g} / \mathrm{g}$ respectively of both elements.

As part of our continuing investigations of the nature of metal complexes in plants which contain high metal concentrations (hyperaccumulators), we have carried out phytochemical studies on five species, of which all except $B$. henriquesi $i$ are endemic to the Shaban metallogenic province. These include three hyperaccumulators of cobalt and/or copper and for comparison, two species with only moderate accumulation of these metals. In addition, manganese was studied in Haumaniastrum robertii. The results of these investigations are reported in this paper.

\section{RESULTS AND DISCUSSION}

\section{Species studied}

The following species were studied: Aeolanthus biformifolius De Wild.; Buchnera henriquesii Engl.; Faroa chalcophila Taylor; Haumaniastrum robertii (Robyns) Duvign. et Plancke; Silene cobalticola Duvign. et Plancke. As all species are annuals, the leaves, which were collected at approximately the same time (March) during the rainy season, were all of about the same age ( 3 months).
Distribution of heavy metals in plant tissue extracts

The distribution of heavy metals in various extracts of plant tissue is shown in Table 1. From this table, several distinct patterns emerge. In all cases, by far the greatest proportion, usually $85-90 \%$, of the heavy metals is found in only three fractions (B, C and $E$ ). These fractions all comprise predominantly polar compounds. Fraction B contains water-soluble polar compounds of relatively low molar mass. In all cases, extraction of copper in this fraction was lower than that of cobalt. This was particularly evident in Haumaniastrum robertii. In previous studies [11], it had been found that most of the nickel $(65-94 \%)$ in nickel hyperaccumulators was readily extractable into deionized water. This compares with a maximum of $42.89 \%$ cobalt in $H$. robertii and $22.16 \%$ copper in $S$. cobalticola.

The more powerful extracting ability of $0.2 \mathrm{M} \mathrm{HCl}$ (fraction $C$ ) resulted in a significantly increased cobalt extraction and usually a greater degree of extraction of copper relative to cobalt. Treatment with perchloric acid (fraction E) gave further significant amounts of copper and cobalt. It is clear, therefore, that most of the cobalt and copper in these plants is bound to organic ligands and that these complexes are all somewhat polar in nature. There is however no simple pattern, in contrast with nickel hyperaccumulators $[12,13]$ where the metal is bound to simple organic acids such as citric acid and malic acid.

The presence of cobalt in plants raises the question of whether it is bound in a cobalamin complex such as vitamin B-12. This, however, is unlikely as such a complex should be extractable in fraction A $195 \%$ ethanolic solvent) which invariably contained insignificant concentrations of cobalt. It should also be mentioned that nonaccumulating plants, fed with cobalt, usually have a high degree of extraction of this element into fraction $A$ 
Table 1. Fractionation of heavy metals in dried leaves of metallophytes from Shaba Province, Zaïre

\begin{tabular}{|c|c|c|c|c|c|c|c|c|c|c|c|}
\hline & \multicolumn{2}{|c|}{ A. biformifolius } & \multicolumn{2}{|c|}{ B. henriquesii } & \multicolumn{2}{|c|}{ F. chalcophila } & \multicolumn{3}{|c|}{ H. rohertii } & \multicolumn{2}{|c|}{ S. cobalticola } \\
\hline & $\mathrm{Cu}$ & Co & $\mathrm{Cu}$ & Co & $\mathrm{Cu}$ & Co & $\mathrm{Cu}$ & Co & $\mathrm{Mn}$ & $\mathrm{Cu}$ & Co \\
\hline Total conens $(\mu \mathrm{g} / \mathrm{g})$ & 3920 & 2380 & 3520 & 1510 & 700 & 134 & 489 & 4690 & 198 & 33 & 233 \\
\hline \multicolumn{12}{|l|}{$\%$ in fractions } \\
\hline$\Lambda$ & 0.8 & 0.5 & 0.1 & 0.1 & 1.4 & 1.2 & 1.7 & 0.2 & 0.8 & 2.5 & 0.5 \\
\hline B & 11.3 & 33.8 & 9.1 & 10.3 & 16.6 & 20.4 & 12.6 & 42.9 & 21.7 & 22.2 & 34.9 \\
\hline $\mathrm{C}$ & 47.8 & 31.7 & 59.3 & 36.3 & 54.6 & 48.9 & 39.9 & 39.7 & 58.7 & 38.8 & 53.4 \\
\hline D & 4.2 & 1.8 & 4.0 & 1.5 & 0.8 & 0.9 & 3.0 & 1.6 & 1.8 & 1.9 & 1.2 \\
\hline $\mathrm{E}$ & 26.0 & 22.0 & 20.7 & 39.6 & 17.4 & 21.3 & 18.3 & 9.9 & 11.6 & 23.2 & 9.0 \\
\hline$F$ & 1.2 & 0.9 & 0.6 & 0.7 & 0.2 & 0.2 & 2.5 & 0.7 & 0.8 & 0.5 & 0.1 \\
\hline$G$ & 1.8 & 8.5 & 2.0 & 7.0 & 3.6 & 4.4 & 7.1 & 4.5 & 4.0 & 5.4 & 0.7 \\
\hline $\mathrm{H}$ & 6.9 & 0.9 & 4.3 & 4.7 & 5.3 & 2.7 & 14.9 & 0.5 & 0.8 & 5.6 & 0.4 \\
\hline
\end{tabular}

A, Neutral small molecules including amino acids and pigments; B, water-soluble low MW polar compounds; C, acid-soluble polar compounds and ions exchanged on cell walls; D, proteins and pectates; $\mathrm{E}$, polar compounds and structural groups such as cellulose and lignins; F, nucleic acids; G, remaining proteins and polysaccharides; H, ccllulose, lignin and immobile fractions on cell walls.

$[14,15]$. This extractability is usually of the order of $30-60 \%$ and contrasts very strongly with that of the hyperaccumulators. The same is true, though to a lesser degree, for copper. The wide distribution of copper and cobalt in at least three fractions, leads to the conclusion that these metals may not be bound to a single ligand.

Statistical analysis of the data of Table 1 shows that there are significant to very highly significant correlations (Table 2) between cobalt and copper levels in the various fractions of each species (intraspecies correlations). Manganese, which was studied only in $H$. robertii, is also strongly correlated with cobalt in the various fractions of this species. This appears to indicate a parallel uptake behaviour for all three elements. When correlations of the proportions of cobalt in the various fractions are calculated for pairs of plant species (interspecies correlations, Table 2), significant correlations are obtained in most cases. When copper is considered, all such correlations are highly significant. This indicates that for both elements there is a similar distribution pattern among the various tissue extracts, for all the species studied here.

Table 2. Statistical data for cobalt and copper associations in plant fractions

\begin{tabular}{|c|c|c|c|c|}
\hline \multicolumn{5}{|c|}{ Intraspecies associations } \\
\hline Code & Species & Variables & $r$ & Significance \\
\hline I & A. biformifolius & Co vs $\mathrm{Cu}$ & 0.75 & $S$ \\
\hline II & B. henriquesii & Co vs $\mathrm{Cu}$ & 0.82 & $\mathrm{~S}$ \\
\hline III & F. chalcophila & Co vs $\mathrm{Cu}$ & 0.99 & $\mathrm{~S}^{* *}$ \\
\hline IV & H. robertii & $\mathrm{Co}$ vs $\mathrm{Cu}$ & 0.69 & $\mathrm{~S}$ \\
\hline & & Co vs $\mathrm{Mn}$ & 0.85 & $\mathrm{~S}^{*}$ \\
\hline V & S. cobalticola & Co vs $\mathrm{Cu}$ & 0.91 & $\mathrm{~S}^{*}$ \\
\hline
\end{tabular}

Interspecies associations (values of $r$ with significances in parentheses)

Cobalt

Copper

\begin{tabular}{|c|c|c|c|c|c|c|c|c|}
\hline & II & III & IV & V & II & 111 & IV & V \\
\hline I & $0.73(\mathrm{~S})$ & $0.87\left(\mathrm{~S}^{*}\right)$ & $0.94\left(S^{* *}\right)$ & $0.89\left(\mathrm{~S}^{*}\right)$ & $0.98\left(S^{* *}\right)$ & $0.97\left(\mathrm{~S}^{* *}\right)$ & $0.96\left(S^{* *}\right)$ & $0.94\left(\mathrm{~S}^{* *}\right)$ \\
\hline II & - & $0.84\left(S^{*}\right)$ & 0.52 (NS) & 0.62 (NS) & - & $0.98\left(\mathrm{~S}^{* *}\right)$ & $0.95\left(\mathrm{~S}^{* *}\right)$ & $0.91\left(\mathrm{~S}^{*}\right)$ \\
\hline III & - & - & $0.83\left(S^{*}\right)$ & $0.93\left(\mathrm{~S}^{* *}\right)$ & - & - & $0.97\left(S^{* *}\right)$ & $0.95\left(S^{* *}\right)$ \\
\hline IV & - & - & - & $0.96\left(S^{* *}\right)$ & - & $\ldots .$. & & $0.92\left(S^{*}\right)$ \\
\hline
\end{tabular}

$\mathrm{S}^{* *}$, very highly significant $(P<0.001)$; $\mathrm{S}^{*}$, highly significant $(0.001 \leqslant P<0.01)$; S, significant $(0.01 \leqslant P<0.05)$; NS. not significant $(P>0.05)$. 


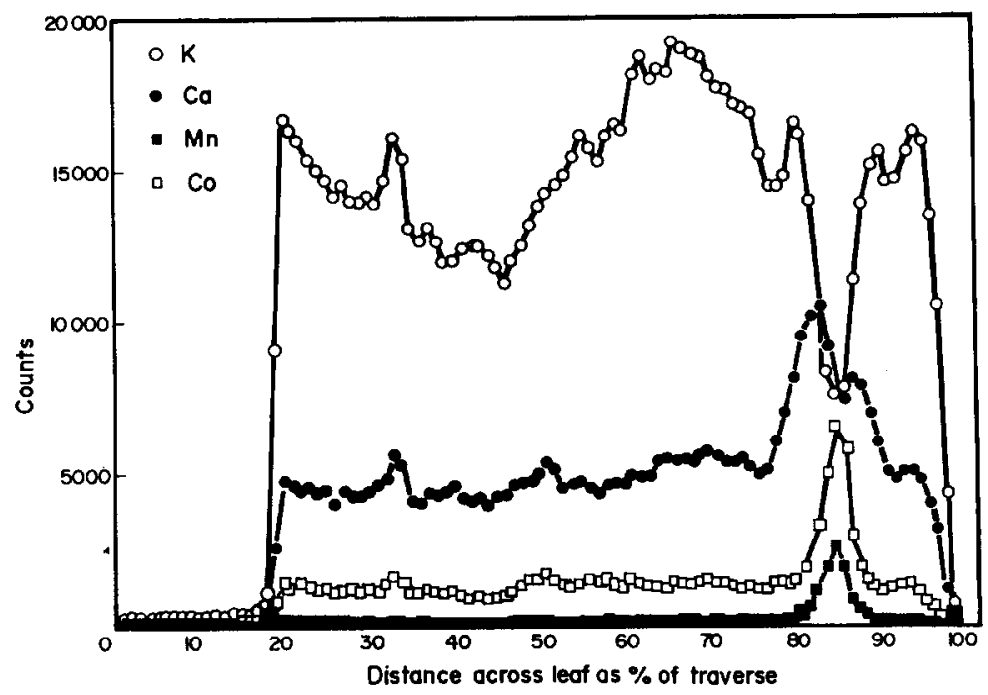

Fig. 1. Proton microprobe scan of leaf of Haumaniastrum robertii showing distribution of potassium, calcium, cobalt and manganese (region occupied by leaf is from 18 to $99 \%$ of traverse distance) and covers a total distance of $6.75 \mathrm{~mm}$.

Spatial distribution of elements in leaves of $\mathrm{H}$. robertii

The spatial distribution of cobalt, manganese, calcium and potassium in leaves of $H$. robertii was investigated with a proton microprobe $[16,18]$. This instrument operates on a principle similar to that of the electron microprobe, but with two important differences. Sensitivity is typically of the order of $1-10 \mu \mathrm{g} / \mathrm{g}$ for many elements and is therefore considerably better than that of the electron microprobe; and measurements may be carried out in air rather than in a vacuum. Photographs of raster pattern scans across a leaf of $H$. robertii showed several regions of elevated cobalt and calcium levels in which there was a corresponding deficiency of potassium.

Figure 1 shows the variation in levels of cobalt, calcium, manganese and potassium as shown by a linear scan chosen to pass through one of these anomalous regions. On a scan with ca $100 \mu \mathrm{m}$ spatial resolution, the distribution of calcium, cobalt and manganese across most of the leaf is remarkably uniform, with concentration variations of no more than $\pm 10 \%$ from the mean. Potassium shows greater variability, of the order of $\pm 20 \%$. The anomalous region, however, shows a much higher concentration of manganese than the remainder of the leaf, and a five-fold increase in cobalt concentration. At the centre of the anomaly there is a substantial decrease in potassium concentration. Surrounding the cobaltmanganese anomaly is a region with elevated calcium levels, although this is slightly less marked at the centre where the cobalt and manganese levels are highest. The diameter of the anomalous region is ca $1 \mathrm{~mm}$.

Evidence has been produced showing the presence of calcium oxalate crystals in the leaves of several plant species [17]. It is possible, in the light of the proton microprobe study, that a significant part of the cobalt in accumulator plants such as $H$. robertii is localized as a salt or complex insoluble in water but soluble in dilute acid Alternatively, it may be possible for $\mathrm{Co}^{2+}$ to replace $\mathrm{Ca}^{2+}$ in the oxalate crystals. This could account for the presence in fraction $\mathrm{C}$ (extraction with $0.2 \mathrm{M} \mathrm{HCl}$ ) of $30-50 \%$ of the total cobalt accumulated.
Further support is provided by the observation that a permanganate titration of an aliquot of fraction $C$, containing $16.6 \mu \mathrm{mol}$ of cobalt, obtained from $H$. robertii, indicated the presence of $18.3 \mu \mathrm{mol}$ of oxalate (assuming that oxalate was the only reducing agent present).

\section{EXPERIMENTAL}

Preparation of tissue extracts. The preparation of tissue extracts is based on the work of ref. [15]. The procedure was as follows: ca $2 \mathrm{~g}$ freeze-dried leaf material was macerated with $10 \mathrm{ml} 95 \%$ EtOH for $5 \mathrm{~min}$ in a bottom-drive homogenizer. The slurry was centrifuged and the residuc washed with further portions of $\mathrm{EtOH}$. The filtered $\mathrm{EtOH}$ extracts (fraction $\mathrm{A}-$ see Table 1) were retained and the residue was then further extracted with two $10 \mathrm{ml}$ portions of deionized water to give fraction $B$. The residue was extracted $\times 3$ with $5 \mathrm{ml}$ portions of $0.2 \mathrm{M} \mathrm{HCl}$. The soluble fraction was treated with an equal vol. of $\mathrm{Me}_{2} \mathrm{CO}$ to precipitate proteins and pectates (fraction D) leaving a supernatant (fraction $\mathrm{C}$ ). The original residue from the acid treatment was then digested at $80^{\circ}$ with $0.5 \mathrm{M} \mathrm{HClO}_{4}$. The supernatant was treated with an equal vol. of $\mathrm{Me}_{2} \mathrm{CO}$ to give a clear soln (fraction $\mathrm{E}$ ) and a ppt. (fraction $\mathrm{F}$ ). The original residue from the $\mathrm{HClO}_{4}$ treatment was then boiled with $2 \mathrm{M} \mathrm{NaOH}$ for 10 min giving fraction $\mathrm{G}$ in the supernatant and fraction $\mathrm{H}$ in the residue.

Analysis of fractions. Metals in tissue extract fractions were determined by atomic absorption spectrophotometry using a Varian-Techtron AAS instrument with continuous background corr. Where fractions consisted of aq. solns, these were analysed directly. In the case of residues and organic solns, these were taken to dryness, ignited at $500^{\circ}$ in a muffe furnace and redissolved in $2 \mathrm{M} \mathrm{HCl}$ hefore analysis. Elements were then determined as above. Oxalate was determined in fraction $\mathrm{C}$ in the following manner: the soln was neutralized with a few drops of $2 \mathrm{M} \mathrm{NaOH}$ and the ppt. was filtered through a Whatman 542 filter paper. After washing with warm deionized water, the ppt. was redissolved in a few $\mathrm{ml}$ conc $\mathrm{H}_{2} \mathrm{SO}_{4}$ followed by dilution to give $c a 1 \mathrm{M}$ acid. The soln was titrated at $60^{\circ}$ with $0.02 \mathrm{M}$ $\mathrm{KMnO}_{4}$. 
Proton microprobe analysis. Proton microprobe studies were carried out at Harvard University and the MIT Lincoln Lab. using a $2 \mathrm{MeV}$ emergent proton beam from a Van de Graaff accelerator. Samples were mounted and scanned past the fixed microbeam by a stepping-motor driven XY stage, with a sample motion and data collection controlled by a minicomputer. 2-D photographic scans (of 5-10 elements simultaneously) were carried out at low resolution $(\approx 150 \mu \mathrm{m})$, forming images of 10000 pixels showing the distribution of each selected element. From these maps we set up 1-D line scans (sensitive to all elements simultaneously) at higher resolution, chosen to pass through interesting features. In all cases the characteristic $X$-rays produced in the front $\approx 20 \mu \mathrm{m}$ of the sample by the proton beam were detected by a $\mathrm{Si}(\mathrm{Li})$ detector and sorted according to pulse height (energy) to determine elemental composition of the sample. The production of a proton micrograph or line scan (all elements at once) typically required $5-10 \mathrm{~min}$.

Acknowledgements-We would like to thank Dr. J. Ryan and the M.I.T. Lincoln Laboratory for the use of their accelerator.

\section{REFERENCES}

1. Duvigneaud, P. (1959) Bull. Soc. R. Bot. Belg. 91, 111.

2. Duvigneaud, P. and Denaeyer-De Smet, S. (1963) Bull. Soc. R. Bot. Belg. 96, 93 .

3. Brooks, R. R. (1977) Plant Soil 48, 541.

4. Brooks, R. R., McCleave, J. A. and Malaisse, F. (1977) Proc. $R$. Soc. Landon, Sec. B 197, 231.
5. Malaisse, F. and Grégoire, J. (1978) Bull. Soc: R. Bot. Belg. 111, 252.

6. Malaisse, F., Gregoire, J., Brooks, R. R., Morrison, R. S. and Reeves, R. D. (1978) Science 199, 887.

7. Brooks, R. R., Morrison, R. S., Reeves, R. D. and Malaisse, F. (1978) Plant Soil 50, 503.

8. Malaisse, F., Grégoire, J., Morrison, R. S., Brooks, R. R. and Reeves, R. D. (1979) Oikos 33, 472.

9. Brooks, R. R., Reeves, R. D., Morrison, R. S. and Malaisse, F. (1980) Bull. Soc. R. Bot. Belg. in press.

10. Morrison, R. S., Brooks, R. R., Reeves, R. D. and Malaisse, F. (1979) Plant Soil 53, 535.

11. Kelly, P. C., Brooks, R. R., Dilli, S. and Jaffré, T. (1975) Proc. R. Soc. London, Sec. B 189, 69.

12. Lee, J., Reeves, R. D., Brooks, R. R. and Jaffré, T. (1977) Phytochemistry 16, 1503.

13. Lee, J., Reeves, R. D., Brooks, R. R. and Jaffre, T. (1978) Phytochemistry 17, 1033.

14. D'Souza, T. J. and Mistry, K. B. (1979) Environ. Exp. Butany 19, 193.

15. Bowen, H. J. M., Cawse, P. A. and Thick, J. (1962) J. Exp. Botany 13, 257.

16. Horowitz, P. and Grodzins, L. (1975) Science 189, 795.

17. Al-Rais, A. H., Myers, A. and Watson, L. (1971) Ann. Botany 35, 1213.

18. Horowitz, P., Aronson, M., Grodzins, L., Ladd, W., Ryan, J., Merriam, G. and Lechene, C. (1976) Science 194, 1162. 